2003, foi encaminhado ao hospital veterinário, um cão, da raça Doberman, macho, 6 anos com suspeita de torção gástrica. $\mathrm{O}$ animal apresentava-se anoréxico e a palpação abdominal observou-se um aumento de volume abdominal em região epi-mesogástrica. Ao atendimento foi realizado um exame radiográfico abdominal em que observou-se homogeniedade da cavidade abdominal sem sinais radiográficos de torção gástríca. $\mathrm{O}$ animal foi então encaminhado ao exame ultra-songráfico sendo visibilizado: dificuldade de avaliação do parênquima hepático, presença de múltiplos nódulos hipoecóicos em alvos entremeados pelo parênquima e contorno irregular; presença de massa arredondada, heterogênea e cavitária de aproximadamente $6,0 \mathrm{~cm}$ de diâmetro em região epi-mesogástrica sugestiva de linfonodo peri-hepático severamente hiperecóico. Foi realizado uma citologia da massa e do líquido abdominal em que verificou presença intensa de neutrófilos tóxicos sugerindo um processo infeccioso severo e peritonite. Ao hemograma o animal apresentava neutrofilia com desvio degenerativo à esquerda. $\mathrm{O}$ animal foi encaminhado a laparotomia exploratória devido a suspeita de peritonite. Na laparotomia não observou-se ruptura de alça ou estômago, sendo visualizado um grave acometimento hepático (atrófico, irregular e com multiplos nódulos) e sinais difusos de peritonite. Devido a estes achados o proprietário optou pela eutanásia e o animal foi encaminhado ao Departamento de Patologia para ser realizado exame necroscópico. O diagnóstico final mostrou um quadro de cirrose hepática associada ao quadro de peritonite bacteriana espontânea. A importância do relato é demonstrar que os casos de cirrose podem apresentar a peritonite espontânea bacteriana sugerindo mau prognóstico para o paciente.

\title{
60 - Megaesôfago em gato. Relato de caso
}

Ushikoshi, W.S.'; Lorigados, C.A.B. ${ }^{2}$; Penha, M.G.B ${ }^{3}$
1- Professor de Clínica de Pequenos Animais da Faculdade de Medicina Veterinária da Universidade de Guarulhos e Universidade Santo Amaro, São Paulo-SP

2-Professora de Diagnóstico por Imagem da Faculdade de Medicina Veterinária da Universidade de Guarulhos e Universidade Santo Amaro, São Paulo-SP

3- Graduanda da a Faculdade de Medicina Veterinária da Universidade de Guarulhos, Guarulhos-SP

O presente trabalho descreve um felino, sem raça definida, fêmea, de três meses de idade, com histórico de regurgitação há aproximadamente duas semanas. O proprietário negava qualquer alteração além dos quadros de "emese", principalmente após a alimentação, de conteúdo alimentar não digerido e formato tubular. Ao exame físico não foi observada desidratação ou caquexia e as funções vitais estavam dentro dos parâmetros normais. Foi realizado exame radiográfico de esôfago simples e esofagograma onde se observou dilatação esofágica total. $\mathrm{O}$ tratamento preconizado foi cimetidina $(10 \mathrm{mg} / \mathrm{kg} / \mathrm{PO}$, a cada 12 horas $)$ e cisapride $(0,5 \mathrm{mg} /$ $\mathrm{kg} / \mathrm{PO}$ ) além do manejo alimentar com dieta pastosa, mantendo o animal em postura bipedal. Após 30 dias, houve diminuição dos eventos de regurgitaçào e após três meses o paciente se apresentava assintomático. Foi realizado exame radiográfico controle onde nào evidenciou a dilatação esofágica. Atualmente, com um ano de idade, $\mathrm{o}$ animal não está sendo medicado $\mathrm{e}$ não apresenta sintomas de regurgitação. $\mathrm{O}$ megaesôfago é caracterizado por uma dilataçào total do esôfago e sua ocorrência em gatos é considerada rara quando comparada em cães, acometendo cerca de $0,05 \%$ dos felinos atendidos. Os principais sintomas variam desde regurgitação, pneumonia ou ambos. Dentre as causas incluem-se a congênita, secundária a esofagite ou doença obstrutiva, decorrente de doença neuromuscular ou ainda idiopática, sendo esta última considerada mais comum. Uma vez que a diminuição da motilidade esofagiana não pode ser avaliada e os aspectos radiográficos não foram compativeis com persistência de arco aórtico direito ou obstrução esofágica, foi realizado uma lista de possiveis diagnósticos de megaesôfago congênito, secundário a esofagite por refluxo ou idiopático. $\mathrm{O}$ tratamento com cisapride e cimetidina foi indicado para aumentar a motilidade esofágica e diminuir a secreçào gástrica, respectivamente, além de evitar ou agravar uma possível esofagite de refluxo. Em càes, os pró-cinéticos nào sào considerados efetivos para o tratamento do megaesôfago, por outro lado, como o esôfago dos felinos é constituído principalmente de 
musculatura lisa, ele pode ser preconizado. A melhora observada neste caso apenas com tratamento sintomático poderia indicar que a causa seria secundária a esofagite de refluxo, porém, como há relatos de remissão espontânea tanto no megaesôfago congênito como no idiopático elas não puderam ser descartadas. Embora raro, o megaesôfago em felinos tem um prognóstico melhor do que em cães, uma vez que a grande maioria dos animais tratados apresentam melhora clínica.

Mariano, C.S. ', Sá, L.R.M ${ }^{2}$ Málaga, S.K.'

\section{1 - Displasia microvascular hepática. Relato de um caso}

1- Médica Veterinária Autônoma

2- Departamento de Patologia da Faculdade de Medicina Veterinária e Zootecnia da Universidade de São Paulo, São Paulo-SP

Displasia microvascular hepática (DMH) é uma doença que se caracteriza por alterações microscópicas da vascularização hepática de cães e gatos. Geralmente, esta entidade está associada a desvio porto-sistêmico macroscópico. E uma desordem vascular congênita, incurável e pouco relatada na literatura. Este trabalho relata ocorrência de $\mathrm{DMH}$ em um cào, caracterizando suas alterações clínicas, laboratoriais e histopatológicas. Um cão da raça Poodle toy, macho, 1 ano e 4 meses, foi examinado clinicamente por apresentar hiporexia, apatia e aumento de volume abdominal há 5 dias. Amostras de urina e sangue foram colhidas para urinálise, hemograma e perfil bioquímico. Foram realizados ultra-sonografia de abdômen e biópsia hepática em cunha. Os fragmentos de fígado foram processados segundo técnica padrào para exame histopatológico e corados por hematoxilina e eosina, Tricrômico de Massom, Azul de Perls e coloração para fibras reticulares. Ao exame clínico foi constatado ascite e o liquido se caracterizou por ser amarelo citrino e com aspecto límpido. $\mathrm{O}$ exame de urina revelou densidade urinária de 1,030; $\mathrm{pH} 5,0$; presença de hemoglobina/eritrócitos + - e cristais de oxalato de cálcio +- O hemograma, bem como os valores bioquímicos de glicose, uréia e creatinina estavam dentro dos valores de referência. Na primeira avaliação da função hepática obteve-se os seguintes resultados: proteínas totais de $3.4 \mathrm{~g} / \mathrm{dl}$, albumina $1.7 \mathrm{~g} / \mathrm{dl}$, globulina $1.7 \mathrm{~g} / \mathrm{dl}$ e ALT $203 \mathrm{U} / \mathrm{l}$. Na segunda, proteínas totais $3.6 \mathrm{~g} / \mathrm{dl}$, albumina $1.6 \mathrm{~g} / \mathrm{dl}$, globulina $2.0 \mathrm{~g} / \mathrm{dl}$ e ALT 253U/le AST $110 \mathrm{U} / \mathrm{L}$. A ultra-sonografia do abdômen mostrou figado de dimensões reduzidas, contornos regulares, ecogenicidade elevada, ecotextura grosseira, e presença de grande quantidade de líquido abdominal livre. Macroscopicamente, os fragmentos de fígado apresentavam contornos irregulares, consistência fibrosa e aspecto lobulado tanto na superfície externa, como na de corte. Microscopicamente, observou-se ausência da veia porta em alguns espaços-portas, dilatação de veia porta, vasos anômalos intralobulares, espessamento de vênulas hepáticas terminais associado ou não a discreto infiltrado linfocítico, diminuição do lóbulo hepático e proximidade entre espaços porta e vênula hepática terminal. Com a coloração de Tricrômico de Masson, evidenciou-se fibrose mural de vênulas hepáticas, algumas com diminuição do lúmen e discreta fibrose portal. Presença de células de Kupffer com pigmentos de hemossiderina, corados pelo azul de Perls, tanto nos espaços periportais, como distribuídas multifocalmente. Ausência de processo necro-inflamatório ou neoplásico hepático no material examinado. As alterações microscópicas observadas são similares as descritas na literatura nos casos de $\mathrm{DMH}$ e, em alguns casos de desvio porto-sistêmico. As alteraçòes clínicas de ambas entidades são similares, contudo os càes somente com $\mathrm{DMH}$, geralmente, apresentam sinais clínicos menos severos e melhor prognóstico a longo prazo. A não observação de encefalopatia hepática sugere ausência de desvio porto-sistêmico macroscópico ou um desvio de menor intensidade. Por outro lado, o diagnóstico definitivo de desvio porto-sistêmico necessita de exames complementares como sintigrafia coloretal, portografia e dosagem pré e pós prandial de ácidos biliares séricos, que não foram realizados por não serem exames utilizados na rotina médico veterinária do nosso meio. A abordagem por laparotomia exploratória, para 